\title{
PERANCANGAN BANGUNAN HUNIAN LANSIA BERDASARKAN AKSESIBILITAS PENGHUNI PADA LINGKUNGAN DAN BANGUNAN
}

\author{
Adriana Sugiharto \\ Magister Arsitektur, Program Pascasarjana, Universitas Katolik Parahyangan, Bandung, Indonesia \\ Email: adriana.sugiharto@gmail.com
}

\begin{abstract}
Abstrak
Perancangan hunian lansia semakin dibutuhkan, akibat angka harapan hidup semakin membaik yang membuat petumbuhan jumlah lansia meningkat. Hunian lansia yang ada telah memiliki citra yang kurang baik didalam masyarakat karena kurangnya perhatian perancangan terhadap kebutuhan lansia yang berbeda. Seperti penyediaan pegangan tangan disekeliling tembok untuk menjaga keseimbangan tubuh ketika berjalan melewati ruang sirkulasi. Permasalahan utama dari aksesibilitas pada bangunan hunian lansia adalah kenyamanan untuk melakukan perpindahan didalam melaksanakan aktivitas kegiatan keseharian lansia. Untuk itu penelitian dilakukan dengan menjadikan teori ergonomi dan anthropometri sebagai acuan dasar dalam membuat analisa kenyamanan aksesibilitas. Penelitian ini bertujuan untuk mengetahui bagaimana pertimbangan perancangan hunian lansia yang mengutamakan kenyamanan aksesibilitas didalam pemenuhan kebutuhan desain yang lebih spesifik didalam aktivitas keseharian. Ini adalah penelitian studi kasus dengan metoda komparatif kualitatif. Penelitian hunian lansia dilakukan dengan dokumentasi foto, catatan, wawancara dan observasi. Melalui hasil analisa penelitian diharapkan untuk menemukan pedoman perancangan hunian lansia berdasarkan tatanan bangunan dan ruang dalam terhadap aksesibilitas. Upaya penelitian untuk membantu seluruh pihak yang ingin memperkaya pembelajaran perancangan tentang merancang aksesibilitas ideal pada hunian lansia.
\end{abstract}

Kata kunci: hunian lansia, ergonomi, anthropometri, aksesibilitas

\begin{abstract}
Title: Design of Residential Building is Based on the Accessibility of the Elderly Residents to the Environment and Building

The design of the elderly housing is increasingly needed, as a result life expectancy has improved which make the growth number of the elderly increases. Senior living for the elderly have had unfavorable image in the community because of a lack of attention to the design of the special needs of the elderly. Like providing the handrail around the wall to maintain the body balance when the elderly walking through the circulation way. The main issue is accessibility in elderly housing for the comfort mobility of the residents to do their daily activity. For that, this research has been done from the ergonomic and anthropometric theory base as a reference in the making of the accessibility comfort analysis. This research are aims to find out how to find senior living design consideration that prioritizes the accessibility comfort of elderly people in the fulfillment of convenience in specific design for everyday activities. Case studies are designed with a qualitative comparative method. Senior living research is taken in the form of photos documentation, notes, interviews and observation. Through the research results are expected to find senior living design guidelines for the elderly based on the building and the space arrangement for accessibility. These research efforts are to help for all those who want to enrich design learning about ideal accessibility in senior living design.
\end{abstract}

Keywords: senior living, ergonomic, anthropometric, accessibility 


\section{Pendahuluan}

Hunian lansia (senior living) yang bermunculan menjadi bagian dari pemenuhan fasilitas suatu perumahan tertentu menjadi daya tarik bagi lansia. Ketersediaan fasilitas ini memiliki perancangan yang sudah di khususkan untuk membantu kemudahan lansia. Mengingat hal tersebut, perlu adanya kesadaran bagi arsitek untuk menciptakan kebutuhan perhatian tersebut didalam desain hunian bangunan bagi para lansia.

Sehingga penelitian ini mengusahakan untuk memberi perhatian yang lebih didalam menargetkan sebuah pengembangan perancangan hunian yang dikhususkan bagi penduduk lanjut usia aktif menegah keatas daerah perkotaan. Peneliti berpendapat bahwa fasilitas hunian bagi lansia di Indonesia mengalami kesenjangan terhadap fasilitas hunian lain di luar negeri. Masih banyak detail perancangan kurang diperhatikan dalam memberi keamanan dan kenyamanan lansia. Sehingga konteks pembangunan perumahan bagi lansia tergolong rendah didalam mendukung keberhasilan penyejahteraan lansia.

Pola aktifitas keseharian lansia menjadi penghubung untuk melihat keterkaitan kenyamanan aksesibilitas yang terjadi didalam suatu hunian lansia. Kebutuhan perancangan ditinjau dari karakteristik, perilaku dan pergerakan lansia terhadap pemakaian didalam aktivitas keseharian. Dilihat dari lingkungan ruang luar seperti pedestrian hingga ruang dalam. Penelitian ini menkhususkan pembelajaran lanjutan akan kehadiran perancangan perumahan hunian bagi lansia yang menerapkan prinsip-prinsip perancangan fasilitas lansia dapat memberikan aksesibilitas ideal. Berdasarkan analisa dari penataan tata ruang luar dan dalam pada sebuah hunian lansia yang dilihat pada pola aktivitas keseharian lansia.

Dari uraian masalah penelitian tersebut, peneliti berharap bahwa dengan adanya penelitian perancangan fasilitas perumahan lansia. Sehingga ilmu arsitektur dapat memberikan kontribusi yang lebih didalam penyediaan bangunan hunian lansia. Dengan tujuan agar dapat menjawab harapan masyarakat terhadap hunian lansia aktif produktif. Terutama didalam mengutamakan kenyamanan aksesibilitas ruang antar ruang dalam dan luar bangunan hunian didalam perancangan.

Tujuan penelitian ini untuk mengidentifikasi langkah-langkah perancangan hunian perumahan lansia yang memberi kemudahan aksesibilitas baik untuk menjalankan kegiatan maupun didalam mendukung penghuni untuk saling berinteraksi. Sehingga hasil perancangan perumahan lansia ini berkompeten dan produktif dalam memperhatikan kebutuhan para lansia dan mampu memberikan suatu lingkungan binaan yang memiliki kualitas suasana lingkungan hidup lebih baik.

Diharapkan hasil penelitian ini dapat digunakan menjadi panduan perancangan senior living bagi lansia di masa mendatang dan mengubah cara pandang masyarakat Indonesia terhadap kehadiran bangunan perumahan lansia yang telah dirancang dengan baik dalam pemenuhan kebutuhan pertumbuhan jumlah lansia. 


\section{Materi dan Metode}

Desain penelitian studi kasus dengan metoda kualitatif komparatif yang bersifat deskriptif. Penelitian kualitatif ini dipilih karena dapat mengamati obyek studi lebih mendalam. Tujuannya adalah menemukan hasil perbandingan analisa perancangan hunian lansia, mulai dari tipologi bangunan hingga program ruang dan penataan ruang hunian sesuai teori aksesibilitas sebagai acuan dasar penelitian. Selain itu landasan teori juga bermanfaat untuk memberikan gambaran umum tentang latar penelitian dan sebagai bahan pembahasan hasil penelitian. Penelitian deskriptif digunakan untuk mendapatkan gambaran tentang hubungan antara kriteria yang ada pada teori aksesibilitas yaitu; keamanan, kemudahan, kenyamanan dan estetika terhadap keberhasilam perancangan fasilitas hunian lansia yang dapat memenuhi kebutuhan fisiologis dan psikologis lansia. Tujuan dari penelitian ini adalah untuk mendapatkan gambaran panduan tentang bagaimana cara merancang perumahan bagi lansia dalam rangka memudahkan aksesibilitas penghuni dari penataan tata bangunan dan ruang dalam. Membuka kemungkinan akan adanya penelitian lanjutan terhadap topik yang dibahas, serta menentukan teknik dan arah yang akan digunakan dalam penelitian berikutnya.

Pengumpulan data berupa dokumentasi dan catatan yang berkaitan dengan perencanaan tata ruang publik dan kritisi terhadap performa ruang publik dengan fenomena-fenomena yang terjadi akibat tatanan bangunan dan ruang dalam di senior living. Pendataan dari wawancara dari penghuni, merupakan kegiatan untuk memperoleh informasi secara mendalam tentang sebuah isu kendala kemudahan aksesibilitas bagi penghuni sebagai tema yang diangkat dalam penelitian. Menyelediki proses pembuktian terhadap informasi atau keterangan yang telah diperoleh untuk mengetahui kemudahan aksesibilitas dari alur kegiatan dan aktivitas lansia didalam keseharian mereka. Observasi langsung dengan kegiatan pencatatan secara sistematik dan pemeriksaan seksama mengenai cara kerja yang berlaku atau yang diusulkan untuk melaksanakan suatu perancangan pada perumahan senior living berkaitan dengan data iklim setempat, fasilitas yang tersedia, dan merekam setiap kegiatan pengguna yang terjadi sepanjang hari didalam dan sekitar kawasan melalui dokumentasi berupa foto. 

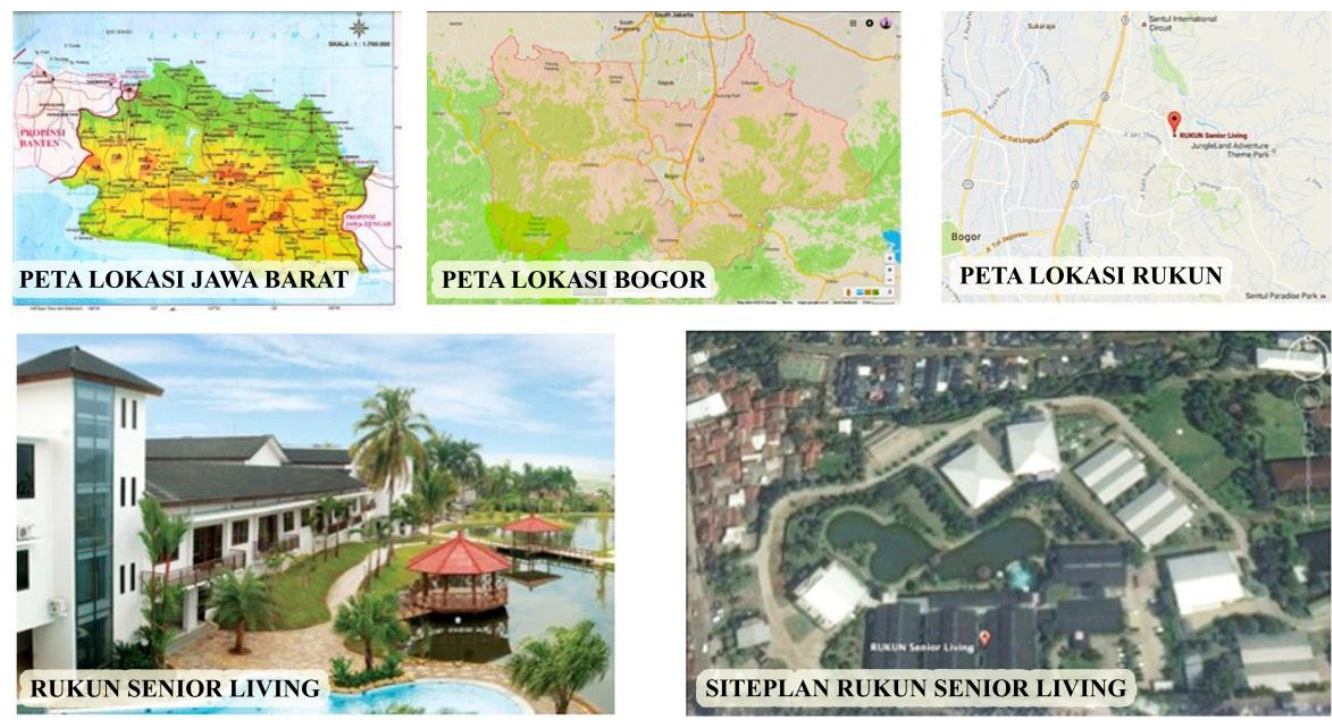

Gambar 1. Obyek studi rukun senior living, Sentul, Bogor

Sumber: Google image, 2016
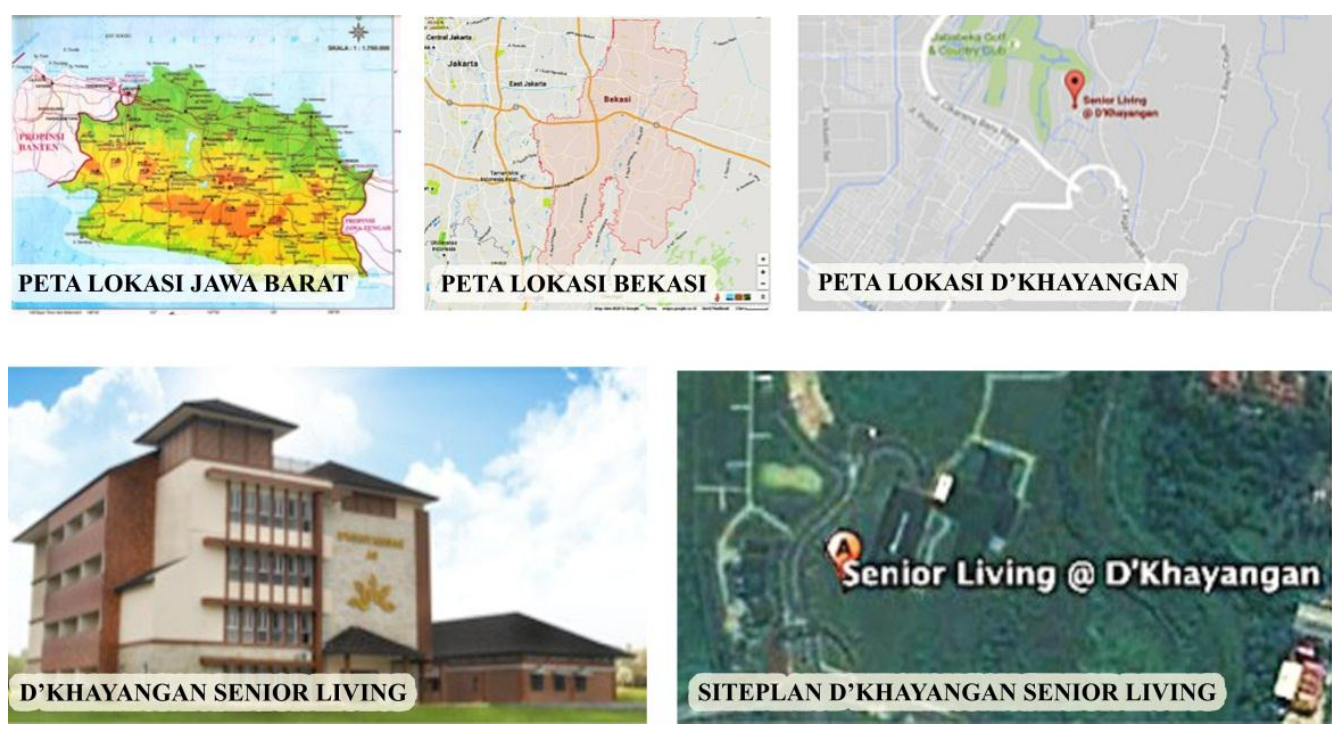

Gambar 2. Obyek studi d'khayangan senior living, Cikarang, Bekasi

Sumber: Google image, 2016

Hasil observasi yang didapat berupa aktivitas, kejadian, peristiwa, objek, kondisi atau suasana tertentu, dan perasaan emosi dari penghuni. Sehingga dapat memperoleh peristiwa atau kejadian dalam menyatakan kenyamanan aksesibilitas. Sasaran yang ingin dicapai dengan penelitian cara kerja ini adalah untuk mendapatkan rancangan tipologi bangunan, tata ruang bangunan, dan perancangan tatanan ruang dalam yang lebih baik. Usaha ini dilakukan dengan cara:

1. Melakukan perbandingan analisa keseluruhan dari keamanan, kemudahan, kenyamanan dan 
estetika yang merupakan dasar teori aksesibilitas diteliti secara keseluruhan dari lingkungan dan ruang dalam pada bangunan.

2. Melakukan analisa ruang gerak dan perbaikan perancangan ruang dalam khususnya pada unit kamar sesuai karakteristik gerak lansia.

Didalam perancangan yang memahami karakteristik lansia terdapat enam karakteristik utama dari lansia diambil dari literatur buku yang berjudul Site Planning and Design for the Elderly oleh Diane Y. Carstens yang berkaitan dengan pemenuhan kebutuhan utama didalam merancang sebuah bangunan hunian lansia. Berikut adalah karakteristik lansia yang memberikan pengaruh pada hubungan lansia dengan lingkungan binaan hunian lansia yaitu: hilangnya keseimbangan tubuh, pemahaman dan ingatan yang menurun, kehilangan kekuatan dalam beraktivitas, kemampuan visual yang berkurang, kemampuan pendengaran yang berkurang, dan meningkatnya sensitivitas terhadap udara dingin, pergantian suasana ekstrim dan sensitivitas pada paparan sinar matahari. Dalam buku Data Arsitek, Neufert mengemukakan keinginan-keinginan para lansia dikaitkan dengan desain, yaitu: Aksesibilitas visual dengan jendela rendah, sehingga dapat melihat keluar sambil duduk. Balkon personal untuk duduk dan bersosialisasi, seperti area berkebun bersama. Perletakan hunian dekat dengan pertokoan. Hunian dapat dipersonalisasi sehingga lansia merasa seperti rumah sendiri. Jalan setapak dengan peneduh dan area peristirahatan di sepanjang jalan. Sistem keamanan dan tanda bahaya kebakaran. Ruang dapur dengan ketinggian meja yang lebih rendah. Ruang tidur sebaiknya disediakan terpisah. Ruang makan dapat di kamar atau di ruang makan bersama.

Perancangan terhadap aksesibilitas lansia memiliki beberapa hal yang perlu diperhatikan (Perkins Bradford, King Houglas \& Cohen eric, Building Type Basic For Senior Living, 2004), antara lain : Jam operasional lift sepanjang waktu. Pintu masuk ruangan otomatis. Menghindari penguncian diri dari dalam ruangan. Papan tanda dilengkapi lampu agar mudah dibaca. Terdapat pengatur temperatur ruangan. Menghindari tanjakan dan permukaan lantai licin. Menyediakan perabot yang sesuai dengan standar gerak lansia. Kamar mandi/wc yang mudah dicapai. Menyediakan tempat makan dengan jendela. Meminimalkan jarak tempuh. (Regnier, Victore, AIA, Assisted Living Housing for The Elderly, 1994) menerangkan bahwa perancangan hunian lansia dapat didasarkan dari dua aspek. Aspek fisiologis terdiri dari; keselamatan dan keamanan, keberadaan dan petunjuk arah, aksesibilitas dan fungsi, serta adaptabilitas. Kedua adalah aspek psikologis antara lain; privasi ruang, interaksi sosial, kemandirian, rasa aman dan tantangan lingkungan, aspek panca indera, keakraban terhadap lingkungan, estetika keseluruhan bangunan, serta personalisasi ruang. 


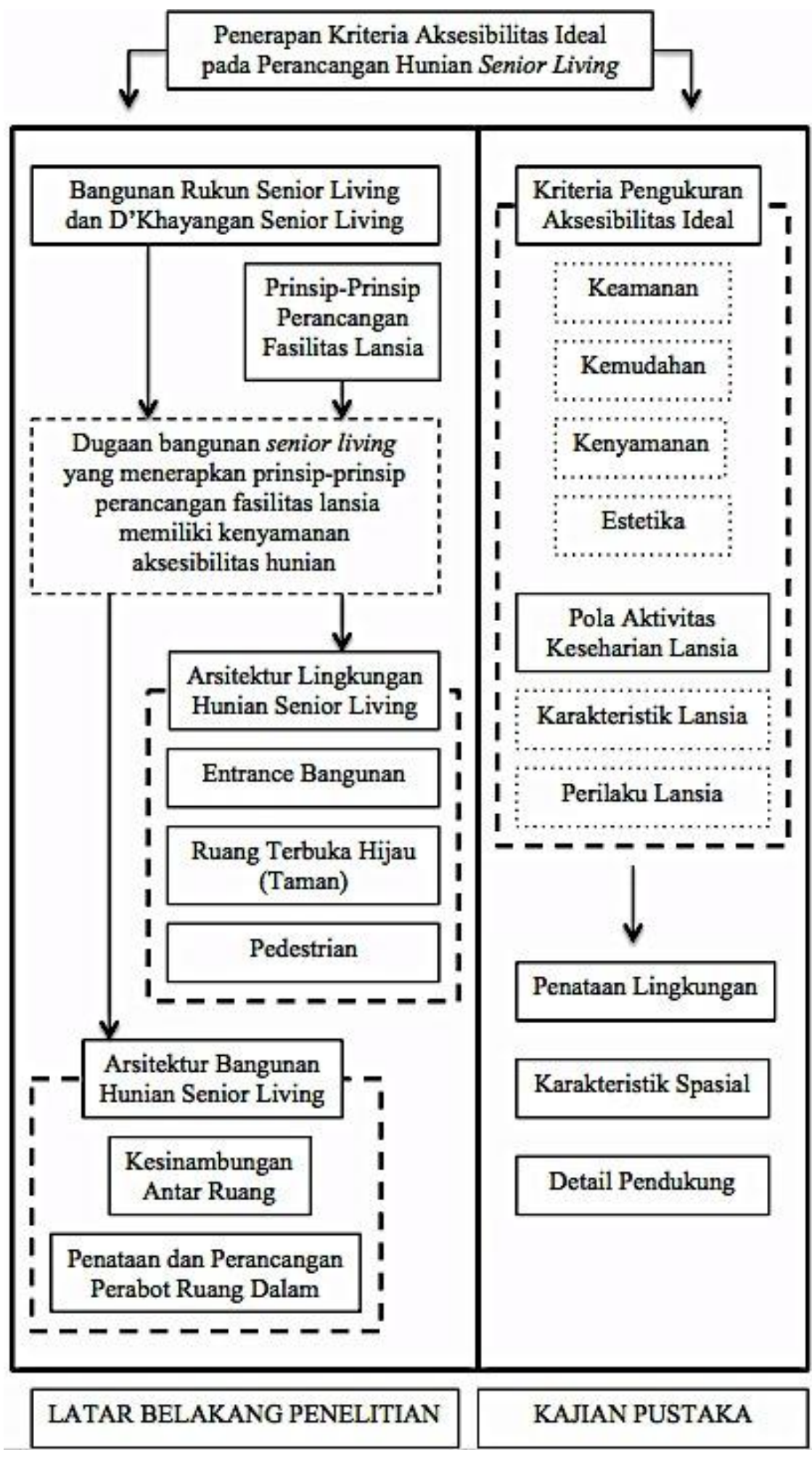

Gambar 3. Kerangka konseptual penelitian

Sumber: Hasil Analisis, 2016 


\section{Hasil dan Pembahasan}

Dilihat berdasarkan tapak dan layout bangunan terhadap aksesibilitas yang terjadi pada jalur sirkulasi bangunan hunian di kedua obyek studi, bangunan hunian D'Khayangan Senior Living lebih dapat memaksimalkan penelitian aksesibilitas ideal karena rancangan bangunan hunian menjadikan pedestrian pada ruang luar terbuka hijau menjadi akses penghubung pada keseluruhan bangunan hunian. Bangunan dibedakan menjadi tiga macam menurut fungsi dan jenis aktivitas yang terjadi didalam bangunan. Bangunan care center menjadi bangunan penerima yang menampung setiap ruang dari penyediaan fasilitas penunjang lansia sehingga bangunan ini ditujukan menjadi wadah bagi ruang aktivitas komunal. Bangunan hunian bertingkat berupa apartemen dan bangunan hunian individual satu lantai berupa vila yang menampung setiap ruang unit kamar lansia sehingga bangunan-bangunan ini menjadi wadah bagi ruang aktivitas yang lebih privat pada ruang komunal dan ruang kamar yang bersifat individual.

Berikut merupakan penjabaran masalahmasalah aksesibilitas yang terkait dari pola sirkulasi dari lingkungan bangunan dan dalam bangunan hunian D'Khayangan Senior living, Cikarang, Bekasi:

1. Adanya perlintasan sirkulasi pada jalur kendaraan menuju care center dengan jalur kendaraan menuju unit hunian villa. Perlintasan jalur ini tidak dirancang dengan baik sehingga dapat membahayakan karena dapat menimbulkan kecelakaan.

2. Sarana penyeberangan yang tidak dirancang dengan baik sehingga dapat membahayakan penghuni yang berjalan kaki.

3. Kompleksitas bangunan yang memiliki ragam tipologi bangunan dimana penghuni harus melakukan mobilisasi melewati ruang luar saat mengakses care center tempat aktivitas publik menuju unit hunian privat mereka yang berupa apartmen dan villa.

4. Karakteristik jalur pedestrian luar yang tidak terlindung dari paparan matahari dan hempasan hujan terlampau jauh dari jarak penyediaan tempat peristirahatan yang teduh.

Bangunan hunian D'Khayangan Senior Living merupakan bangunan hunian yang terpisah oleh ruang terbuka hijau dan terhubungkan pedestrian. Dimana banyak terladapat perancangan arsitektur lingkungan pada ruang terbuka hijau sebagai elemen penghubung ruang yang menjembatani alur mobilisasi yang harus ditempuh penghuni didalam mengakses fasilitas. Untuk itu pedestrian membentuk rute sirkulasi yang ada pada bangunan hunian di keseluruhan tapak siteplan bangunan. Layout perancangan bangunan secara umum merupakan hubungan aksesibilitas dari lingkunngan dan bangunan hunian pada care center sebagai bangunan penerima dan pusat aktivitas publik komunal pada aktivitas bersama untuk penghuni, dengan apartmen sebagai kumpulan unit individual didalam sebuah bangunan bertingkat, dan dengan villa sebagai kumpulan yang lebih kecil pada bangunan-bangunan individual.

Kurangnya tempat peristirahatan untuk duduk dan berteduh pada jalur pedestrian merupakan permasalahan utama yang ada pada bangunan hunian. Dimana karakteristik lansia yang 
membutuhkan kemudahan dan kedekatan jarak untuk menjangkau area peristirahatan saat mobilisasi merupakan hal utama didalam perancangan aksesibilitas ideal. Keperluan dari penyediaan toilet pada jalur sirkulasi juga menjadi masalah yang patut diperhatikan. Menanggapi kebutuhan akan kemampuan lansia didalam toleransi mereka untuk menggunakan toilet. Dan bagaimana pedestrian mempertemukan penghuni untuk bersosialisasi disaat mereka menuju aktivitas kegiatan pada fasilitas bangunan yang berbeda. Kurangnya ruang publik yang dapat menciptakan sosialisasi yang intim membuat ruang pada jalur sirkulasi bangunan tidak didapati terjadinya interaksi yang baik pada sesame penghuni. Untuk itu perancangan pada area duduk sebagai area peristirahatan seharusnya dapat menyediakan kesempatan lansia selain untuk menikmati pemandangan juga dapat memberi kesempatan mereka berinteraksi didalam menjalin hubungan kekeluargaan yang dapat mendukung ketenangan dan kesehatan mereka.

Permasalahan utama dari aksesibilitas pada bangunan hunian D'Khayangan Senior Living adalah kenyamanan untuk melakukan perpindahan didalam melaksanakan aktivitas kegiatan keseharian lansia. Gagasan peracangan terkait isu aksesibilitas pada lingkungan dan bangunan hunian dapat dirangkum pada beberapa tahapan penerapan yang utama yaitu:

1. Pemenuhan aksesibilitas ideal pada sistem sirkulasi lingkungan bangunan. Area kedatangan pada bangunan dimana jalur kendaraan bermotor memiliki keteraturan dalam mengantar penghuni dan kenyamanan ruang tunggu bagi pendatang. Perancangan ruang terbuka hijau (taman) yang mendukung terjadinya interaksi sosial dan area semiprivat untuk bersantai menikmati pemandangan. Pedestrian dimana penghuni dengan nyaman diberi kemudahan menjangkau area teduh peristirahatan dan toilet yang diletakkan pada jalur sirkulasi ruang luar.

2. Pemenuhan aksesibilitas ideal pada sistem sirkulasi didalam ruang bangunan. Kesinambungan antar ruang yang membentuk urutan suasana ruang pada sirkulasi aktivitas keseharian lansia. Penataan dan perancangan perabot ruang dalam dirancang dalam beberapa macam tipe rancangan didalam menjawab tiap-tiap kebutuhan lansia aktif dan difable didalam fasilitas dan penataan serta perancangan perabot yang terdapat didalamnya.

Gagasan perancangan ini dilakukan agar dapat memberikan altenatif desain yang lebih sesuai berdasarkan kesimpulan dari pedoman desain. Sehingga mendapat efesiensi dan efektivitas dari aksesibilitas pada bangunan baik pergerakan didalam ruang dan pergerakan antar ruang yang terjadi didalam bangunan menjadi fokus pembahasan penelitian. Dikaitkan dengan analisa perletakan tata ruang dan tata ruang dalam yang berkaitan dengan pemakaian ruang didalam alur kegiatan keseharian lansia. Aspek-aspek perancangan unit vila yang terkait dengan aksesibilitas ruang dijabarkan dengan membagi menjadi dua bahasan utama. Pertama adalah analisa pada lingkungan, pada bagian terdapat tiga aspek bahasan yaitu pada entrance bangunan, ruang terbuka hijau (taman), 
dan pedestrian. Bagian kedua adalah analisa terhadap bangunan. Menjabarkan dua aspek yaitu tentang kesinambungan antar ruang yang terdapat pada tatanan denah dan menjabarkan analisa terhadap penataan dan perancangan perabot didalam ruang. Potensi didalam gagasan perancangan pada bangunan hunian D'Khayangan Senior Living yang terkait dengan kenyamanan aksesibilitas penghuni pada lingkungan dan bangunan hunian sebagai berikut:

1. Penggunaan jalur pedestrian didalam keseluruhan tapak merupakan jalur sirkulasi yang penting didalam menghubungkan ruang aktivitas komunal dan publik pada bangunan care center dengan bangunan hunian unit yang bersifat lebih privat pada bangunan apartemen dan villa. Sehingga intensitas mobilisasi pada jalur pedestrian tinggi karena setiap penghuni haru melewati pedestrian didalam melakukan aktivitas kegiatan keseharian mereka.

2. Jalur sirkulasi aksesibilitas pada bangunan hunian D'Khayangan Senior Living memberikan aktivitas yang lebih dibandingkan jalur aksesibilitas pada bangunan hunian Rukun Senior Living. Dimana dominasi aksesibilitas yang terjadi pada Rukun Senior Living hanya terjadi didalam bangunan. Untuk itu pada jalur perpaduan sirkulasi indoor dan outdoor pada bangunan hunian D'Khayangan Senior Living memberikan tantangan pemecahan perancangan yang berbeda.

\section{Perancangan Lingkungan Unit Vila \\ Aksesibilitas}

Aksesibilitas Entrance Lansia

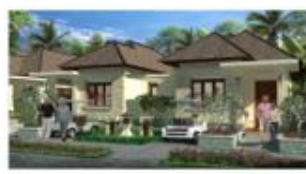

AREA ENTRANCE UNIT VILA
MEMIUKI PATIO DAN TAMAN YANG DAPAT PERSONALISA PADA TIAP BANGUNAN

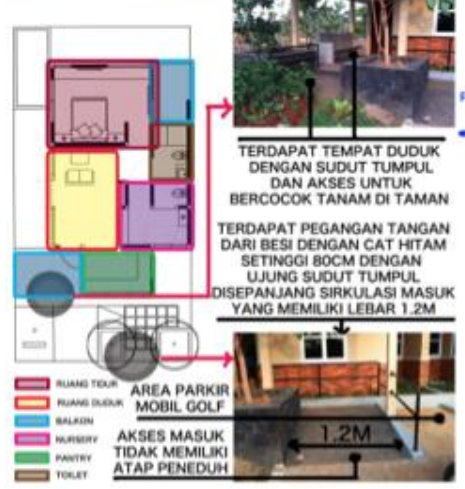

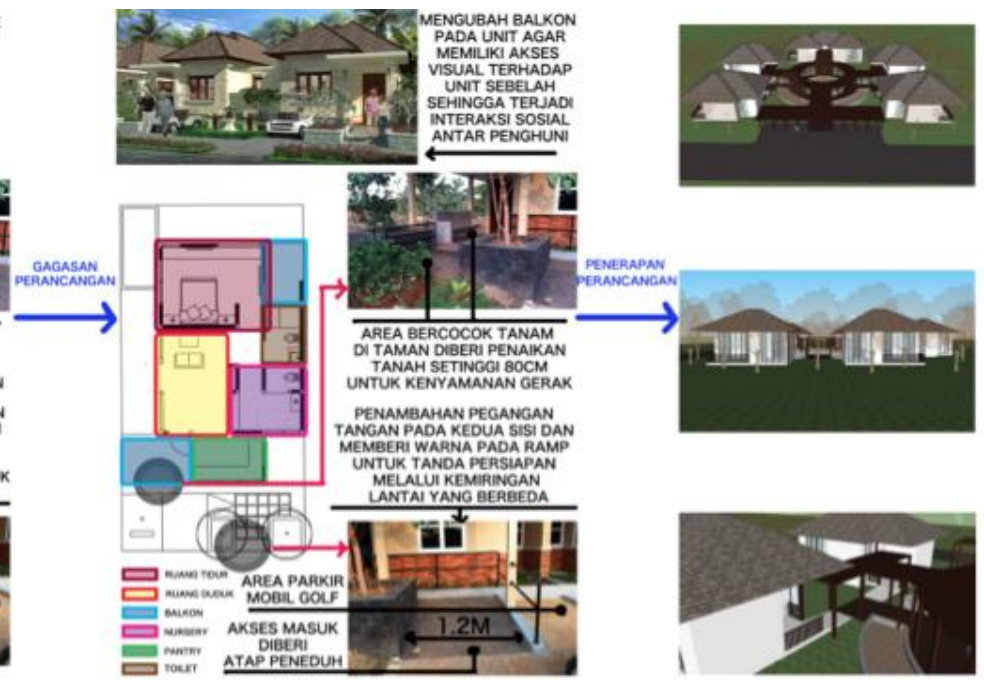

Gambar 4. Entrance dan lingkungan unit vila d'khayangan senior living, Cikarang, Bekasi Sumber: Hasil Analisis, 2016 


\section{Aksesibilitas Ruang Terbuka Hijau Lansia (Taman)}

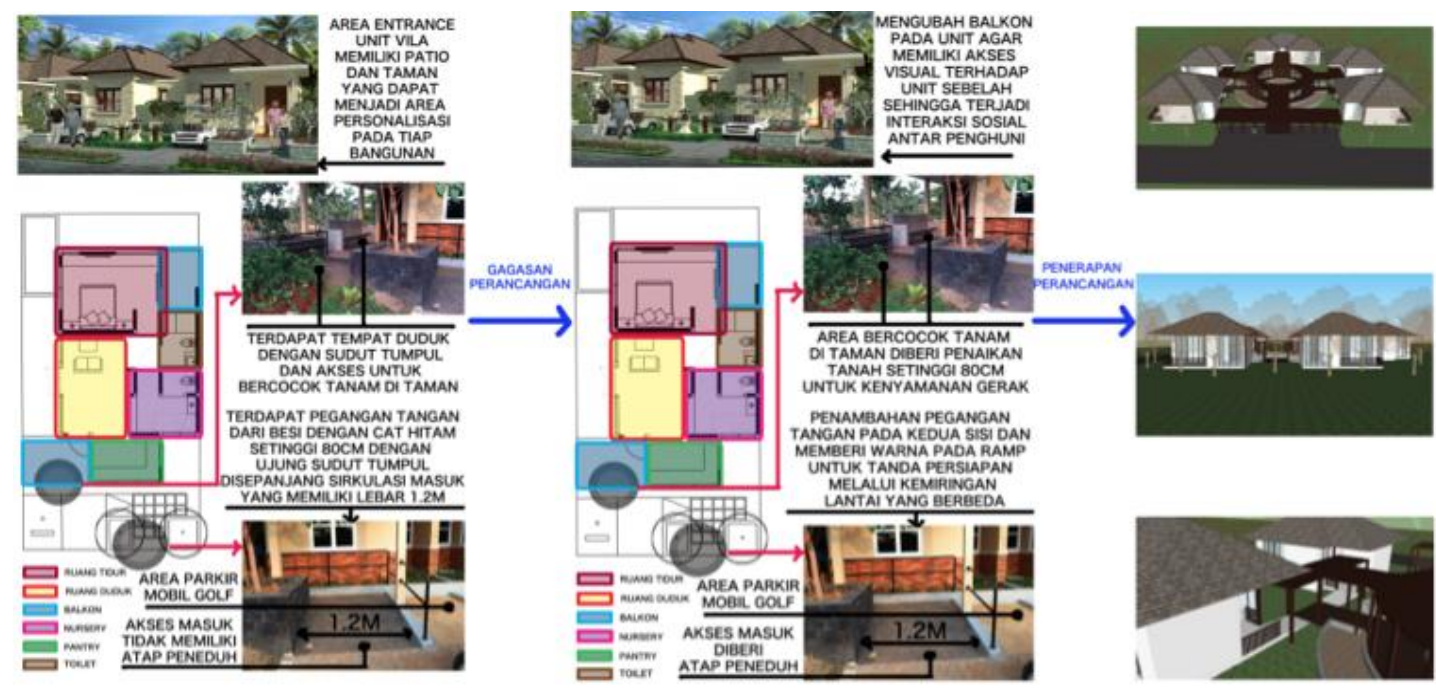

Gambar 5. Perancangan aksesibilitas ruang terbuka hijau hunian vila d'khayangan senior living, Cikarang, Bekasi

Sumber: Hasil Analisis, 2016

\section{Aksesibilitas Pedestrian Lansia}
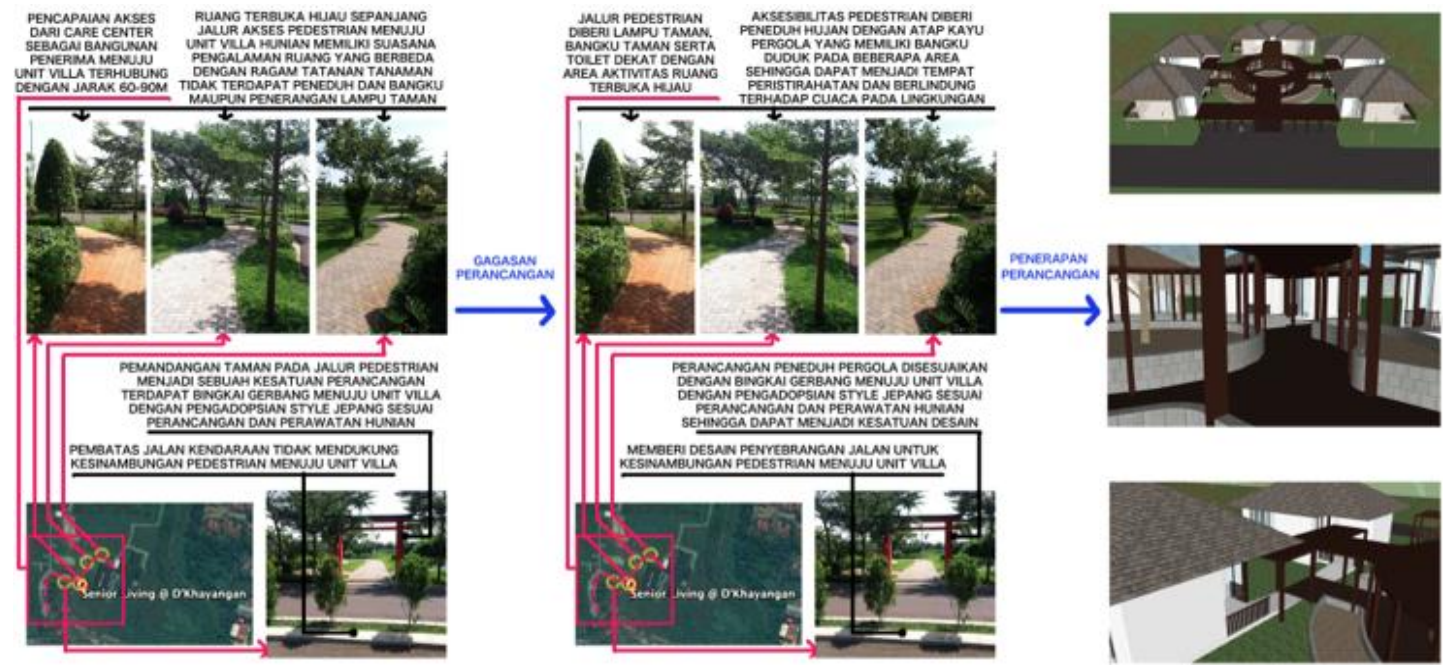

Gambar 6. Perancangan jalur pedestrian unit vila d'khayangan senior living, Cikarang, Bekasi Sumber: Hasil Analisis, 2016 


\section{Perancangan Aksesibilitas \\ Bangunan Unit Vila}

\section{Aksesibilitas dan Sirkulasi Ruang Dalam Lansia}
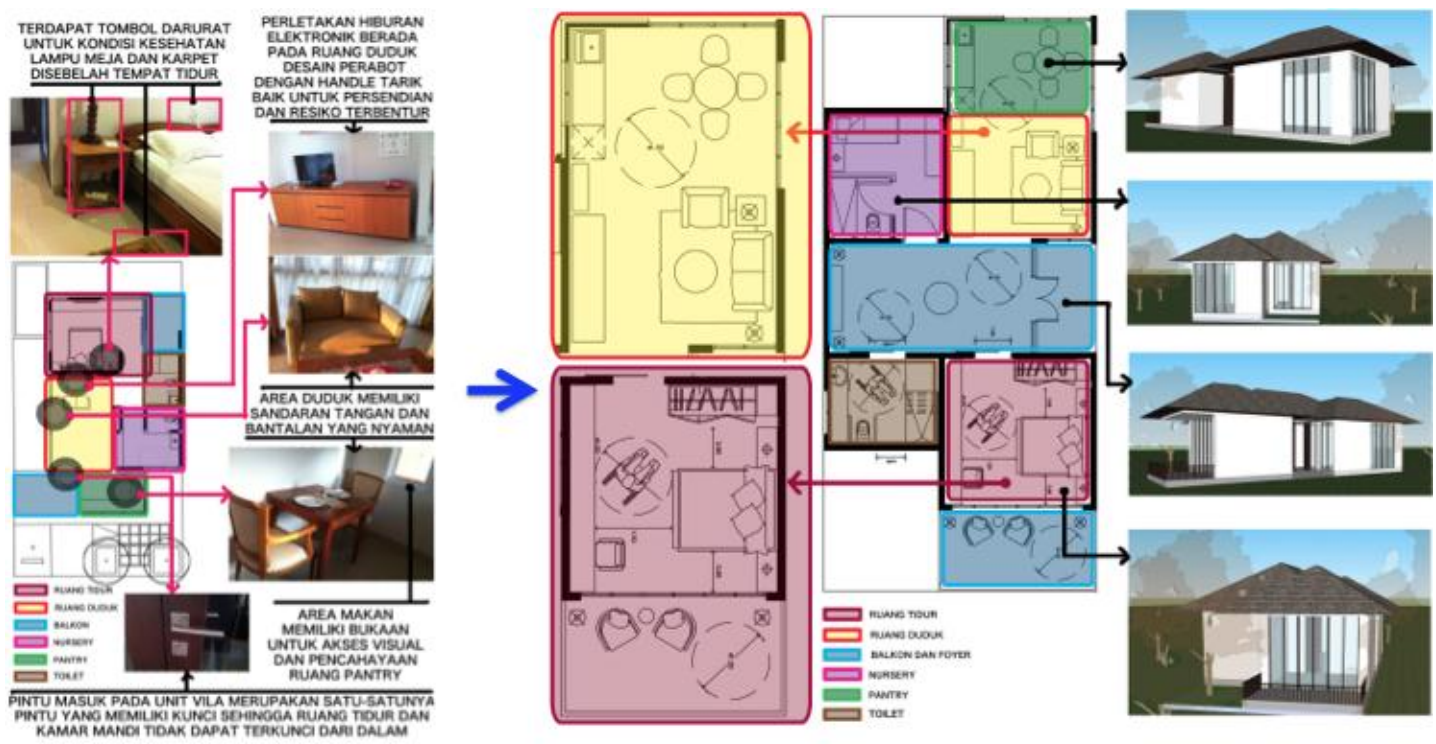

Gambar 7. Perancangan unit vila tipe deluxe d'khayangan senior living, Cikarang, Bekasi Sumber: Hasil Analisis, 2016

\section{Aksesibilitas dan Sirkulasi Kamar Mandi}
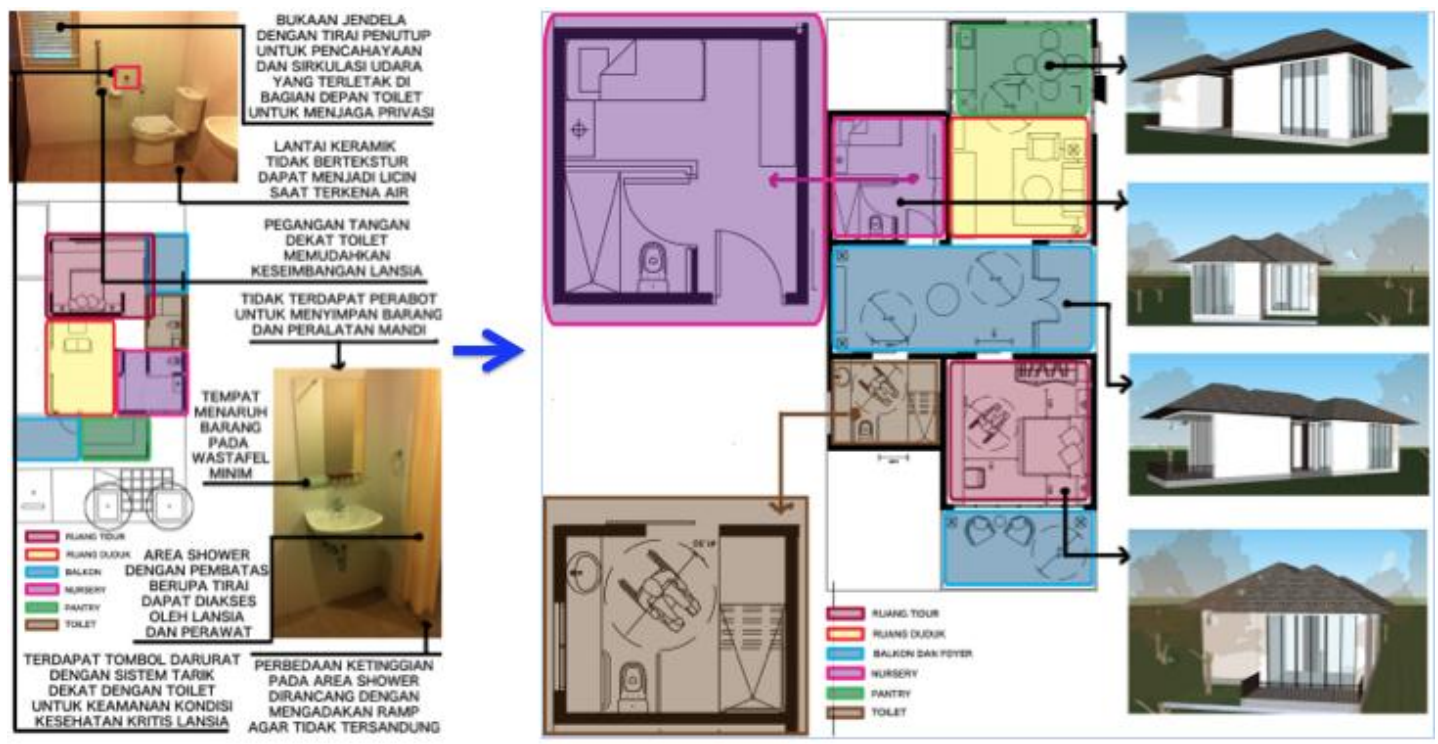

Gambar 8. Perancangan kamar mandi unit vila d'khayangan senior living, Cikarang, Bekasi

Sumber: Hasil Analisis, 2016 
Pada kedua penjabaran potensi didalam gagasan perancangan pada bangunan hunian D'Khayangan Senior Living jalur pedestrian didalam aksesibilitas lebih banyak digunakan sehingga memiliki potensi pengembangan gagasan perancangan yang lebih luas. Dari adanya gagasan penerapan perancangan dari pedoman desain aksesibilitas ideal pada bagian akhir dari hasil penelitian yang telah dicapai, diharapkan perancangan lingkungan binaan pada bangunan hunian lansia D'Khayangan Senior Living dapat menjadi pembelajaran yang dapat menyediakan perumusan pedoman desain yang tepat bagi penyediaan aksesibilitas ideal pada lansia. Sehingga perancang dapat mengembangkan perhatian lebih akan adanya perbedaan kebutuhan dari perancangan bangunan hunian para lansia.

\begin{tabular}{|c|c|}
\hline Lokasi Elemen Perancangan & Pedoman Desain \\
\hline \multirow[t]{2}{*}{ 1.) Jalur masuk tapak } & $\begin{array}{l}\text { Pertimbangan Perancangan: keamanan, kemudahan aksesibilitas } \\
\text { dan identifikasi. }\end{array}$ \\
\hline & $\begin{array}{l}\text { 1. Bangunan masih berada didalam jarak pengelihatan dari } \\
\text { arah jalan pada tapak. } \\
\text { 2. Gerbang masuk harus mudah di identifikasi. } \\
\text { 3. Memiliki keamanan dari keramaian jalan. } \\
\text { 4. Jalan masuk yang banyak membantu tapak yang luas. } \\
\text { 5. Kemudahan akses untuk lansung menuju fasilitas kesehatan } \\
\text { dan fasilitas perbelanjaan di sekitar lokasi tapak. }\end{array}$ \\
\hline \multirow[t]{2}{*}{ 2.) Jalur masuk bangunan } & $\begin{array}{l}\begin{array}{l}\text { Pertimbangan Perancangan: Kemudahan dan keamanan } \\
\text { aksesibilitas. }\end{array} \\
\end{array}$ \\
\hline & $\begin{array}{l}\text { 1. Perencanaan tatanan layout memudahkan bangunan untuk } \\
\text { dikenal dan di identifikasi. } \\
\text { 2. Tidak mencampurkan jalur kendaraan searah dengan jalur } \\
\text { kendaraan dua arah. } \\
\text { 3. Kemudahan untuk keluar dan masuk kendaraan didalam } \\
\text { tapak bangunan. } \\
\text { 4. Jarak dekat dan nyaman menuju akses masuk ke bangunan. }\end{array}$ \\
\hline \multirow[t]{2}{*}{ 3.) Area kedatangan } & $\begin{array}{l}\text { Pertimbangan Perancangan: Kemudahan akses, keamanan, } \\
\text { kenyamanan, pemandangan, nuansa bangunan yang menarik } \\
\text { perhatian. }\end{array}$ \\
\hline & $\begin{array}{l}\text { 1. Posisi utama pada area kedatangan adalah untuk akses } \\
\text { pengawasan dan area pelayanan didalam menyambut } \\
\text { pendatang baru. } \\
\text { 2. Area kedatangan haruslah terlindung dari terik matahari dan } \\
\text { hempasan hujan. } \\
\text { 3. Orientasi harus melindungi bangunan dari kondisi cuaca. } \\
\text { 4. Aksesibilitas area kedatangan tidak memiliki kemiringan } \\
\text { lebih dari } 2.5 \text { persen. } \\
\text { 5. Memiliki kemudahan akses jalan pedestrian menuju } \\
\text { bangunan lain pada tapak. } \\
\text { 6. Area penurunan penumpang diposisikan untuk selalu } \\
\text { berada di sebelah kiri. } \\
\text { 7. Area duduk terlindung dari terik matahari dan hujan namun } \\
\text { tetap memiliki akses melihat pemandangan luar. } \\
\text { 8. Area duduk harus menyediakan akses keluar dan masuk }\end{array}$ \\
\hline
\end{tabular}




\begin{tabular}{|c|c|}
\hline & $\begin{array}{l}\text { bangunan sehingga dapat melihat keramaian jalur yang } \\
\text { akan ditempuh penghuni. }\end{array}$ \\
\hline \multirow[t]{2}{*}{$\begin{array}{l}\text { 4.) Entrance unit bangunan } \\
\text { individual }\end{array}$} & $\begin{array}{l}\text { Pertimbangan Perancangan: Kemudahan akses, kemudahan } \\
\text { pengenalan, keamanan dan privasi, kenyamanan, nuansa } \\
\text { bangunan yang menarik. }\end{array}$ \\
\hline & $\begin{array}{l}\text { 1. Perlindungan terhadap terik matahari dan hempasan hujan } \\
\text { pada area akses. } \\
\text { 2. Kelangsungan akses menuju jalan penghubung dari area } \\
\text { parkir menuju pintu masuk bangunan. } \\
\text { 3. Pintu masuk bangunan memiliki pembedaan pada setiap } \\
\text { unit bangunan agar memudahkan untuk diidentifikasi. } \\
\text { 4. Jalan menuju area masuk bangunan dapat merupakan area } \\
\text { gabungan yang bersifat privat berupa unit bangunan. }\end{array}$ \\
\hline \multirow[t]{2}{*}{ 5.) Lahan parkir } & Pertimbangan Perancangan: Kemudahan akses dan keamanan. \\
\hline & $\begin{array}{l}\text { 1. Dekat dan mudah untuk mengakses entrance. } \\
\text { 2. Diletakan pada lokasi yang mudah terlihat untuk } \\
\text { keamanan. } \\
\text { 3. Tidak mendominasi pemandangan dan area kedatangan } \\
\text { utama. } \\
\text { 4. Kumpulan kecil area parkir disetiap kluster bangunan akan } \\
\text { memudahkan aksesibilitas lansia terutama pada tapak yang } \\
\text { sangat luas. } \\
\text { 5. Parkir difable berdekatan dengan entrance. } \\
\text { 6. Jalur kendaraan searah dan dua arah tidak bercampur pada } \\
\text { sirkulasi jalan pedestrian dan jalur sepeda. } \\
\text { 7. Mudah di orientasikan pada bangunan. } \\
\text { 8. Jalur kendaraan memiliki kesinambungan dari jalur masuk, } \\
\text { drop off dan parkir. }\end{array}$ \\
\hline \multirow[t]{2}{*}{ 6.) Taman rekreasi aktif } & $\begin{array}{l}\text { Pertimbangan Perancangan: Keamanan, kemudahan akses, } \\
\text { kenyamanan, dan estetika. }\end{array}$ \\
\hline & $\begin{array}{l}\text { 1. Didekatkan dengan aktivitas utama seperti balkoni outdoor } \\
\text { pada ruang komunal. } \\
\text { 2. Dapat diletakan berjauhan dengan bangunan untuk zonasi } \\
\text { yang lebih tenang dan santai. }\end{array}$ \\
\hline \multirow[t]{2}{*}{ 7.) Taman rekreasi pasif } & $\begin{array}{l}\text { Pertimbangan Perancangan: Kemudahan, kenyamanan, dan } \\
\text { estetika. }\end{array}$ \\
\hline & $\begin{array}{l}\text { 1. Didekatkan pada bukaan bangunan untuk memberi akses } \\
\text { pemandangan bagi penghuni dari dalam bangunan. } \\
\text { 2. Berada jauh untuk eksplorasi dan retreat. }\end{array}$ \\
\hline \multirow[t]{2}{*}{ 8.) Area bercocok tanam } & $\begin{array}{l}\text { Pertimbangan Perancangan: Fleksibilitas pergantian jenis } \\
\text { tanaman, kemudahan penggunaan dan kenyamanan. }\end{array}$ \\
\hline & $\begin{array}{l}\text { 1. Berada dekat dengan bangunan dan unit kamar penghuni } \\
\text { pada zonasi yang berbeda. } \\
\text { 2. Tidak mendominasi pemandangan bangunan dan aktivitas } \\
\text { luar. } \\
\text { 3. Diletakan mengenai matahari langsung. }\end{array}$ \\
\hline \multirow[t]{2}{*}{ 9.) Sirkulasi pedestrian } & $\begin{array}{llll}\text { Pertimbangan } & \text { Perancangan: Keamanan, } & \text { kemudahan, } \\
\text { kelangsungan akses, kenyamanan dan } & \text { kemudahan } \\
\text { penjangkauan, dan estetika. }\end{array}$ \\
\hline & $\begin{array}{l}\text { 1. Penataan jalur memudahkan untuk mengidentifikasi } \\
\text { keberadaan dan tujuan perpindahan pada bangunan. } \\
\text { 2. Akses keluar masuk bangunan yang mudah. } \\
\text { 3. Kemiringan jalur maksimal } 10 \text { persen dan pada jalur }\end{array}$ \\
\hline
\end{tabular}




\begin{tabular}{|l|l|}
\hline & $\begin{array}{l}\text { utama maksimal 5 persen. } \\
\text { 4. Sirkulasi melewati aktivitas publik untuk memberi } \\
\text { kesempatan bersosialisasi. }\end{array}$ \\
5. Terdapat hirarki dari rute utama pada komunitas yang \\
besar sehingga membutuhkan sirkulasi yang lebar, hingga \\
menuju unit kamar pada jalur lebih kecil. \\
6. Permukaan pedestrian haruslah nyaman dan aman bagi \\
pergerakan lansia. \\
7. Jalur sirkulasi harus memberikan kedekatan akses untuk \\
area toilet dan peristirahatan. \\
8. Tambahan papan petunjuk jalan sangat membantu lansia \\
didalam menentukan arah tujuan kegiatan yang dituju.
\end{tabular}

Tabel 1. Pedoman perancangan arsitektur lingkungan hunian senior living Sumber: Hasil Analisis, 2016

\begin{tabular}{|c|c|}
\hline Lokasi Elemen Perancangan & Pedoman Desain \\
\hline \multirow[t]{2}{*}{ 1.) Area komunal } & $\begin{array}{l}\text { Pertimbangan Perancangan: } \\
\text { aksesibilitas dan identifikasi. }\end{array}$ \\
\hline & $\begin{array}{l}\text { 1. Kedekatan akses menuju fasilitas lain. } \\
\text { 2. Penghubung seluruh fasilitas dan kegiatan. } \\
\text { 3. Memiliki hirarki dari ruang publik dan privat. } \\
\text { 4. Ruang duduk dengan kenyamanan beragam. } \\
\text { 5. Setiap ruang komunal harus memiliki citra tertentu } \\
\text { untuk mengorientasikan diri. } \\
\text { 6. Ruang komunal terlalu banyak akan membingungkan. } \\
\text { 7. Kualitas dan kuantitas dari pencahayaan pada ruang } \\
\text { yang ideal untuk dipandang. } \\
\text { 8. Tidak memberi kontras ruang dari gelap dan terang } \\
\text { karena mengganggu pengelihatan. } \\
\text { 9. Intensitas keramaian suara perlu seimbang dari volume } \\
\text { ruang dan banyak orang. } \\
\text { 10. Kemudahan dan kedekatan untuk mengakses toilet dan } \\
\text { area peristirahatan. }\end{array}$ \\
\hline \multirow[t]{2}{*}{ 2.) Area servis \& loading } & $\begin{array}{l}\text { Pertimbangan Perancangan: Kemudahan, keamanan dan } \\
\text { privasi aksesibilitas. }\end{array}$ \\
\hline & $\begin{array}{l}\text { 1. Tidak mengganggu aktivitas lansia untuk mengakses } \\
\text { fasilitas bangunan. } \\
\text { 2. Mendukung pencitraan servis hunian yang disampaikan } \\
\text { kepada komunitas. } \\
\text { 3. Tidak mendominasi pemandangan. } \\
\text { 4. Servis dari kebutuhan pendukung penghuni berdekatan } \\
\text { dengan unit kamar. }\end{array}$ \\
\hline \multirow[t]{2}{*}{ 3.) Area staff pengelola } & $\begin{array}{l}\text { Pertimbangan Perancangan: Kenyamanan, keamanan dan } \\
\text { privasi aksesibilitas. }\end{array}$ \\
\hline & $\begin{array}{l}\text { 1. Tidak mendominasi ruang namun tidak juga terisolasi } \\
\text { dari keseluruhan bangunan. } \\
\text { 2. Memiliki akses area servis ke unit hunian. } \\
\text { 3. Keamanan dan pencahayaan baik pada area kerja. } \\
\text { 4. Terdapat akses pemandangan untuk melihat kelancaran } \\
\text { pelayanan terhadap penghuni. }\end{array}$ \\
\hline 4.) Sirkulasi bangunan & $\begin{array}{l}\text { Pertimbangan Perancangan: Kemudahan, kenyamanan, } \\
\text { keamanan dan estetika. }\end{array}$ \\
\hline
\end{tabular}




\begin{tabular}{|c|c|}
\hline & $\begin{array}{l}\text { 1. Kemudahan jarak jangkauan antar urutan aktivitas } \\
\text { keseharian. } \\
\text { 2. Kenyamanan pergantian suasana ruang. } \\
\text { 3. Membentuk pola yang mudah diidentifikasi. } \\
\text { 4. Memiliki hirarki dari publik ke privat untuk memberi } \\
\text { penghuni rasa aman dan kontrol. } \\
\text { 5. Akses menuju unit hunian tidaklah harus melewati ruang } \\
\text { fasilitas aktivitas komunal. } \\
\text { 6. Penataan ruang memiliki zonasi semiprivat dan } \\
\text { mendukung interaksi sosial penghuni. } \\
\text { 7. Meminimalkan sirkulasi yang berpapasan jalur } \\
\text { pedestrian, sepeda, dan kendaraan. } \\
\text { 8. Merancang runtutan perjalanan yang memiliki skema } \\
\text { suasana ruang berbeda sehingga nyaman untuk dilalui. } \\
\text { 9. Ramp dan perbedaan ketinggian harus diberi warna } \\
\text { cerah untuk tanda pembeda. } \\
\text { 10. Tangga cukup lebar untuk beristirahat dengan maksimal } \\
\text { 10 anak tangga. }\end{array}$ \\
\hline 5.) Taman rekreasi pasif & $\begin{array}{l}\text { Pertimbangan Perancangan: Keamanan, kemudahan akses, } \\
\text { kenyamanan, dan estetika. }\end{array}$ \\
\hline & $\begin{array}{l}\text { 1. Menjaga ruang terbuka dengan memberi taman kering } \\
\text { sebagai area peristirahatan. } \\
\text { 2. Memberi transisi ruang melewati taman pasif sebelum } \\
\text { melakukan aktivitas outdoor. } \\
\text { 3. Diletakan ditengah ruang aktivitas untuk } \\
\text { memaksimalkan daya guna pemandangan. } \\
\text { 4. Sirkulasi jalan didalam bangunan melewati taman kering } \\
\text { yang memiliki area duduk merupakan pergantian } \\
\text { suasana yang baik. } \\
\text { 5. Area taman kering pasif didalam bangunan sebaiknya } \\
\text { terlindung dari paparan terik matahari dan hempasan } \\
\text { hujan. }\end{array}$ \\
\hline 6.) Unit kamar & $\begin{array}{l}\text { Pertimbangan Perancangan: Keamanan, kemudahan, } \\
\text { peristirahatan dan kenyamanan. }\end{array}$ \\
\hline & $\begin{array}{l}\text { 1. Furnitur ruang dapat dipindah sesuai ketertarikan } \\
\text { penghuni. } \\
\text { 2. Memiliki teras depan untuk memberi personalisasi } \\
\text { ruang. } \\
\text { 3. Sirkulasi ruang dalam dan bukaan pintu cukup leluasa } \\
\text { untuk pengguna kursi roda. } \\
\text { 4. Memiliki penutup lantai anti-slip dan anti-glare di setiap } \\
\text { ruang. } \\
\text { 5. Pada unit kamar terdapat tombol emergency untuk } \\
\text { kondisi kesehatan dan keamanan. } \\
\text { 6. Jendela menyediakan pemandangan dan penyinaran } \\
\text { matahari tidak langsung. } \\
\text { 7. Memiliki balkon dengan pemandangan taman. } \\
\text { 8. Terdapat handrail ruang dan perancangan pegangan } \\
\text { bukaan tidak menghantar panas dan nyaman bagi } \\
\text { pergerakan sendi. }\end{array}$ \\
\hline 7.) Kamar mandi & $\begin{array}{l}\text { Pertimbangan Perancangan: Keamanan, kemudahan, } \\
\text { penerangan. }\end{array}$ \\
\hline
\end{tabular}




\begin{tabular}{|c|c|}
\hline & $\begin{array}{l}\text { 1. Memiliki penutup lantai anti-slip. } \\
\text { 2. Sebaiknya menggunakan shower yang memiliki tempat } \\
\text { duduk. } \\
\text { 3. Harus terdapat tombol emergency. } \\
\text { 4. Pintu tidak terdapat kunci yang dari dalam. } \\
\text { 5. Memiliki ruang yang bebas dan bukaan pintu leluasa } \\
\text { untuk pergerakan difable. }\end{array}$ \\
\hline \multirow[t]{2}{*}{ 8.) Ruang duduk \& pantry } & $\begin{array}{l}\text { Pertimbangan Perancangan: Keamanan, kemudahan, } \\
\text { penerangan dan kenyamanan. }\end{array}$ \\
\hline & $\begin{array}{l}\text { 1. Furnitur ruang dapat dipindah sesuai penghuni. } \\
\text { 2. Memiliki penutup lantai anti-slip dan anti-glare. } \\
\text { 3. Sirkulasi ruang leluasa untuk kursi roda. } \\
\text { 4. Perancangan pegangan bukaan perabot tidak menghantar } \\
\text { panas, nyaman bagi jangkauan dan pergerakan sendi. } \\
\text { 5. Tidak menyediakan benda tajam dan pemanas gas. } \\
\text { 6. Microwave dan pemanas air diperbolehkan. } \\
\text { 7. Ruang duduk dapat melihat pemandangan. } \\
\text { 8. Penyinaran tidak langsung pada jendela. } \\
\text { 9. Ruang duduk dapat dipersonalisasi. }\end{array}$ \\
\hline \multirow[t]{2}{*}{ 9.) Balkon unit kamar } & $\begin{array}{l}\text { Pertimbangan Perancangan: Keamanan, privasi, kenyamanan } \\
\text { dan penerangan. }\end{array}$ \\
\hline & $\begin{array}{l}\text { 1. Sebaiknya tetap terlindung dari paparan terik matahari } \\
\text { dan hempasan hujan. } \\
\text { 2. Cukup luas untuk peletakan kursi dan meja untuk } \\
\text { bersantai melihat pemandangan. }\end{array}$ \\
\hline
\end{tabular}

Tabel 2. Pedoman perancangan arsitektur bangunan hunian senior living

Sumber: Hasil Analisis, 2016

\section{Kesimpulan}

Lansia memiliki karakteriktik kebutuhan ruang yang berbeda. Kebutuhan perhatian perancangan yang memerlukan aksesibilitas ideal sesuai dengan kebutuhan fisiologis dan psikologis lansia. Hunian senior living dapat menjadi lingkungan binaan yang tepat bagi lansia apabila penyediaan aksesibilitas ideal sebagai sarana mobilisasi lansia didalam suatu bangunan hunian terintegrasi dengan baik terhadap penyediaan lokasi, fasilitas dan pengelolaan operasional yang mendukung secara ekonomi, kualitas pelayanan dan lingkungan.

Karakteristik dari jalur akses yang ideal memerlukan dua bagian besar perancangan yang harus diperhatikan. Pertama adalah perancangan di lingkungan bangunan hunian yang meliputi perancangan entrance bangunan, perancangan ruang terbuka hijau (taman), dan perancangan pedestrian. Kedua perancangan di dalam bangunan yang meliputi perancangan kesinambungan antar ruang dimana akan terbentuk alur sirkulasi dari pola aktivitas keseharian. Kemudian perancangan dan penataan perabot ruang dalam yang akan menjadi fasilitas pendukung terbesar dimana lansia memiliki unit ruang kamar sebagai zonasi ruang paling privasi bagi mereka untuk menghabiskan sebagian besar kegiatan.Didalam perancangan tersebut, aksesibilitas ideal perlu melakukan 
pendekatan yang lebih teliti lagi terhadap penataan lingkungan, karakteristik spasial dan detail pendukung dari tiap-tiap perancangan yang ada pada bangunan hunian senior living.

Dari hasil penelitian yang telah didapat dari keseluruhan penelitian perancangan bangunan hunian senior living lansia dapat dikembangkan lebih lanjut kedalam perancangan bangunan hunian yang berbeda sesuai dengan adaptibilitas lansia terhadap suatu lingkungan binaan. Penelitian perancangan bangunan hunian lansia berdasarkan aksesibilitas penghuni pada lingkungan dan bangunan dapat menjadi salah satu dukungan dari pengembangan perancangan. Setiap perancangan akan memiliki dampak dari adaptibilitas lansia yang berbeda sesuai dengan karakteristik dan gaya hidup lansia. Pada penelitian selanjutnya akan memungkinkan hasil yang berbeda pada keberlanjutan pengembangan

perancangan yang berbeda.

\section{Daftar Pustaka}

John, Wiley \& Sons, Inc. (1993). Site Planning and Design for The Elderly.

Neufert, Ernest. (192). Data Arsitek Jilid 2. Erlangga, Jakarta.

Perkins, Bradford. (2004). Building Type Basics for Senior Living. John Wiley \& Sons, New York.

Regnier, Victor, AIA. (1994). Assisted Living Housing for The Elderly. Van Noutrand Reinhold, New York. 
Jurnal Teknik Arsitektur ARTEKS, Volume. I, Nomor 2, Juni 2017 ISSN 2541-0598 